\author{
Lyudmyla Niemets \\ DSc (Geography), Professor, Head of the Department of Human Geography and Regional Studies \\ e-mail: soc-econom-region@karazin.ua,ORCID ID: https://orcid.org/0000-0001-9943-384X \\ Maryna Lohvynova \\ PhD Student of the Department of Human Geography and Regional Studies \\ e-mail: logvinova_mari94@ukr.net, ORCID ID: https://orcid.org/0000-0003-3190-710X \\ Yuriy Kandyba \\ PhD (Geography), Assistant Professor of the Department of Human Geography and Regional Studies \\ e-mail: kand77@ukr.net, ORCID ID: https://orcid.org/0000-0003-1155-057X

\section{Lyudmyla Klyuchko} \\ PhD (Geography), Assistant Professor of the Department of Human Geography and Regional Studies \\ e-mail: liudmylakliuchko@gmail.com, ORCID ID: https://orcid.org/0000-0001-6937-3364

\section{Oleksiy Kraynukov} \\ DSc (Geography), Associate Professor of the Department of Ecological Safety and Environmental Education \\ e-mail: alkraynukov@gmail.com, ORCID ID: https://orcid.org/0000-0002-5264-3118 \\ V.N. Karazin Kharkiv National University, Svobody Sq., 4, Kharkiv, 61022, Ukraine
}

\title{
TRANSFORMATION OF THE AGRARIAN SPHERE OF UKRAINE: APPROACHES TO STUDY
}

The relevance of the study is due to the absence in the scientific literature of an unambiguous definition of the concept of "transformation of the agrarian sphere." In our understanding, the transformation of the agrarian sphere is a socio-geographical process that is characterized by a change in the sectoral, territorial structure and system of the agrarian sphere on different scales, caused by the transformation of the entire economic system or certain of its structural elements. The reasons for significant changes in the agrarian sphere of Ukraine is the change in the socio-political, economic and other spheres, the heterogeneity of natural conditions and the demographic situation. The beginning of the agrarian transformation in Ukraine is considered the period of its independence, since there was a transition from the command-administrative economic system to the market one. However, due to the lack of clear goals of transformation, this process did not bring the expected results.

Transformational processes of the agrarian sphere are the driving force of the socio-economic development of the regions, especially in the rural areas, since they contribute to the stabilization of the economic, ecological, social spheres of the life of the rural population; ensure an increase in the quality of life of the population, provide equal opportunities for achieving material, ecological and social well-being, improving the quality of the state of the environment, developing nature management in the national interests of the country and preserving resources for future generations, life expectancy and stabilization of the population of Ukraine.

Scientific novelty of the work consists in studying the transformational processes of the agrarian sphere from the standpoint of social geography, considering the transformation as a socio-geographical process, identifying the factors of these processes and the relationship of the agrarian sphere with the socio-economic development of the regions.

Keywords: agrarian sphere, transformation processes, transformation of the agrarian sphere, agriculture, transformation cycle.

Людмила Немець, Марина Логвинова, Юрій Кандиба, Людмила Ключко, Олексій Крайнюков. ТРАНСФОРМАЦІЯ АГРАРНӦ̈ СФЕРИ УКРАЇНИ: ПІДХОДИ ДО ВИВЧЕННЯ

Проаналізовано поняття «аграрна сфера», подано ії структуру, визначено співвідношення понять, пов'язаних 3 аграрною сферою: «аграрний сектор» та «агропромисловий комплекс». Розглянуто сутність понять «трансформація аграрної сфери» 3 позицій суспільно-географічного підходу. Визначено чинники виникнення трансформаційних процесів в аграрній сфері України. Подано періодизацію аграрних трансформацій на теренах України, їх еволюцію, проаналізовано думки щодо початку процесів аграрної трансформації в Україні та причин небажаних наслідків. Проаналізовано сучасні напрямки протікання трансформаційних процесів в аграрній сфері України. Розглянуто структуру стратегії трансформації аграрної сфери України та досягнення позитивних ефектів у результаті трансформації.

Ключові слова: аграрна сфера, трансформаційні процеси, трансформація аграрної сфери, сільське господарство, трансформаційний цикл.

Людмила Немеи, Марина Логвинова, Юрий Кандыба, Людмила Ключко, Алексей Крайнюков. ТРАНСФОРМАЦИЯ АГРАРНОЙ СФЕРЫ УКРАИНЫ: ПОДХОДЫ К ИЗУЧЕНИЮ

Проанализировано понятие «аграрная сфера», представлена её структура, определено соотношение понятий, касающихся аграрной сферы: «аграрный сектор» и «агропромышленный комплекс». Рассмотрена сущность понятий «трансформация аграрной сферы» с позиций общественно-географического подхода. Определены факторы возникновения трансформационных процессов в аграрной сфере Украины. Представлена периодизация аграрных трансформаций на территории Украины, их эволюция, проанализированы мнения относительно начала процессов трансформации в аграрной сфере Украины и причин нежелательного результата. Проанализированы современные направления протекания трансформационных процессов в аграрной сфере Украины. Рассмотрена структура стратегии трансформации аграрной сферы Украины и достижение положительных эффектов в результате трансформации.

Ключевые слова: аграрная сфера, трансформационные процессы, трансформация аграрной сферы, сельское хозяйство, трансформационный цикл. 
Introduction to the research problem. The agrarian sphere occupies a leading place in the formation, effective development and functioning of all economic systems, this is a nucleus around which a number of socio-economic problems are being solved, regardless of the volume of production of agrarian products and its share in the gross domestic product. After the proclamation of Ukraine as an independent state, there have been significant changes in the socio-political and economic spheres that led to changes in the agrarian sphere. These reforms are the most important component of the socioeconomic development of the country and its regions, the driving force for increasing the competitiveness of the agricultural sector, changing the specialization of agriculture, expanding its economic potential, ensuring national food security, create conditions for the growth of incomes and welfare of the rural population, introduction of new technologies, rational use of available natural resources.

The relevance of this research topic is due to the low efficiency of the agrarian sector of Ukraine, a number of problems that arose in the adaptation of agricultural production to market conditions, emergence of new forms of economic structures, complex and contradictory movement of the transformation processes that led to a decrease in the efficiency and competitiveness of agriculture, increasing territorial differences in the development of the agrarian sector. Therefore, there is a need for a comprehensive socio-geographical study of the nature and characteristics of the transformation processes in the agrarian sphere, their impact on the socio-economic development of the country as a whole and its regions.

Literature review. Modern foreign and domestic economic literature is characterized by a profound theoretical and methodical analysis of all areas of transformation processes, including in the agrarian sphere. Among foreign scientists, it should be noted H. Bakhchev [27], who studied the features of the transformation processes in Bulgaria, K. Kovacs [29] and D. Karacsonyi [30] - in Hungary, J. Banski [28] - in Poland. Significant contribution to the development of this problem was made by Russian scientists: M. Gaitz [3], N. Hrazhevska [4], I. Leshchyk [7], V. MeselVeselyak [12], S. Mochernyi [13], A. Onyshchenko [14], T. Ostashko [15], T. Pepa [16], H. Pyrih [7], T. Sabluk [19], R. Smolenyuk [20], L. Chernyuk [26], V. Yurchyshyn [14], etc. These scientists studied transformation processes in the agrarian sphere from the standpoint of the economic approach at the state level and did not consider transformation processes at the regional level.

The representatives of the human geography have significant experience in studying transformation processes in the agrarian sphere. Thus, N. Baranovsky considered transformational processes in rural areas, Yu. Kachaev, V. Smal - in the development of the economy, V. Nahirna - in the development of individual branches of agriculture, P. Sukhyi - transformation of agro-industrial complex [23]. Transformation of the agrarian sphere was investigated by H. Balabanov [2], M. Zaiachuk [5], T. Kravets [6], A. Marushchynets [10, 11, 17], V. Nahirna, H. Pidhrushnyi [17], L. Rudenko,
Ya. Sosnytska [21, 22], and P. Sukhyi [23]. The contribution to the theoretical and methodological apparatus of human-geographical studies of transformation processes in the agrarian sphere is the work of Ya. Sosnytska (Modern Transformation Processes of Agricultural Production (on the Example of the Volyn Region, 2015) [21] and A. Marushchynets (Transformation of the Agrarian spheres and social and economic development of the Kiev Dnieper area) 2016 [11].

Despite the rather large number of publications on transformational processes in the agrarian sphere, the essence of the concept of "transformation of the agrarian sphere" requires a certain clarification and generalization from the standpoint of the human-geographical approach. Such a study will reveal the territorial features of the course of transformation processes, will help to identify the advantages and disadvantages of such processes in the territories of the regional and local level and their impact on social and economic development. In addition, human-geographical studies of the transformational processes of the agrarian sphere in the territorial aspect with an analysis of the causes of occurrence and peculiarities of the passing, were almost not carried out, which is promising for further research.

The aim of the article is to systematize and generalize human-geographical studies of transformational processes in the agrarian sphere of Ukraine, to reveal their influence on the social and economic development of the regions. According to the goal, tasks were set: to analyze the essence of the concept of "transformation of the agrarian sphere" from the perspective of human geographers, to determine the causes and features of the transformation processes in the agrarian sphere of Ukraine, to analyze the impact of the transformation of the agrarian sphere on the socio-economic development of the regions.

Results. Today there are two approaches to the interpretation of the term "agrarian sphere". According to the first approach, the basis of the agrarian sphere is agriculture. In accordance with the second approach, the agrarian sphere includes social, economic, scientific and technical, environmental aspects of the development of agricultural production and processing of agricultural products, including the entire agro-industrial complex with the existing system of links [11]. The term "agrarian sphere" refers to a complex of branches of the economy that includes agricultural production, processing and marketing of agricultural products, agrarian and sociocultural relations within rural areas [8].

The notions "agrarian sphere" is associated with such categories as "agrarian sector", "agro-industrial complex" (Fig. 1). The agrarian sector is a broader concept than the "agrarian sphere", since it includes agriculture and fisheries, the food industry, processing of agricultural products, science and education, social sphere of the village, its material and technical and financial support [18]. Concerning the agro-industrial complex, the agrarian sphere is its first basic link $[6,11]$.

A. Marushchynets calls the agrarian sphere as an industrial-territorial system that consists of three components: agriculture, territory with its natural conditions and resources, population with its labor resources (the 
driving force of the functioning and development of the agrarian sphere) [10].

The functions of the agrarian sphere are to ensure the social and economic development of rural areas development of the village in a spiritual and material sense, development of infrastructure, cultural and spiritual facilities; food - providing the population with food; raw materials - providing enterprises with agricultural raw materials [21].

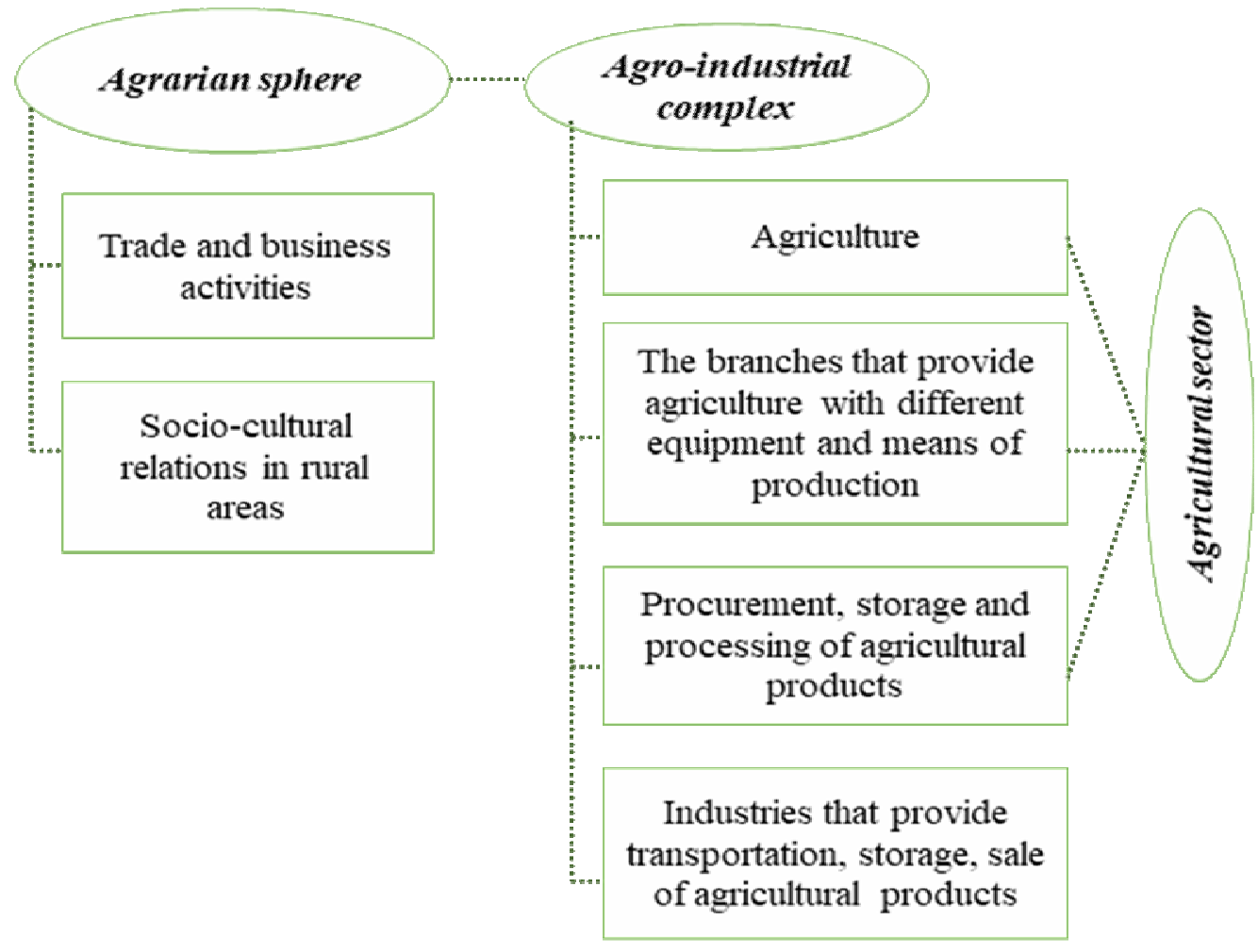

Fig. 1. The correlation of concepts related to the agrarian sphere (improved by the authors for [6])

The development of the agrarian sphere is very complicated process, as it proceeds under the influence of various socio-economic factors, it was especially felt during the transition from an administrative-command to a market economy model. This process is defined as a process of transformation, which requires a comprehensive socio-geographical justification and comprehension $[10,22]$.

The term "transformation of the agrarian sphere" requires a certain clarification, since the study of transformational processes in the agrarian sphere without a clear authoritative definition is impossible. We offer to consider some known definitions of the concept of "transformation of the agrarian sphere."

M. Malik, I. Leshchyk, H. Pyrih (2007) under the term "transformation of the agrarian sphere" is understood as a way of removing contradictions between market requirements and the outdated logic of the behavior of economic entities, which consists in the implementation of organizational, economic, financial and economic, legal, technical measures, aimed at reorganizing enterprises, changing the forms of ownership, management, organizational and legal form, which contributes to the financial recovery of the economy, increasing the output of competitive goods production, increase in production efficiency [7, 9].

T. Kravets (2012) calls transformations in the agrarian sphere as a socio-geographical process that charac- terizes the historical changes in the form, structure and system of the agrarian sphere, conditioned by the scientific and technological revolution, qualitative changes in economic and social processes [6].

R. Smolenyuk (2014) under agrarian transformations understands the gradual transition of agriculture from the command-administrative to the market system of management, through changes in the aggregate of economic, technological, environmental, social and political processes that ultimately lead to a new quality of economic system of the industry [20].

A. Marushchynets (2016) defines the term "transformation of the agrarian sphere", calling it the process of structural changes, which causes the formation of a new quality of the agrarian sphere and its adaptation to new conditions of functioning within a certain territory [11].

From the standpoint of the human geography of the transformation of the agrarian sphere, according to the system-structural approach, it represents the process of changing the institutional, sectoral, territorial nature of the agrarian sector in the region, conditioned by the transformation of the entire economic system. The main factors that predetermine the existence of such transformations is change in the socio-political, economic, institutional systems, diversity of the natural conditions of the territory, demographic situation, social infrastructure, ecological state (Fig. 2) [2, 17]. 


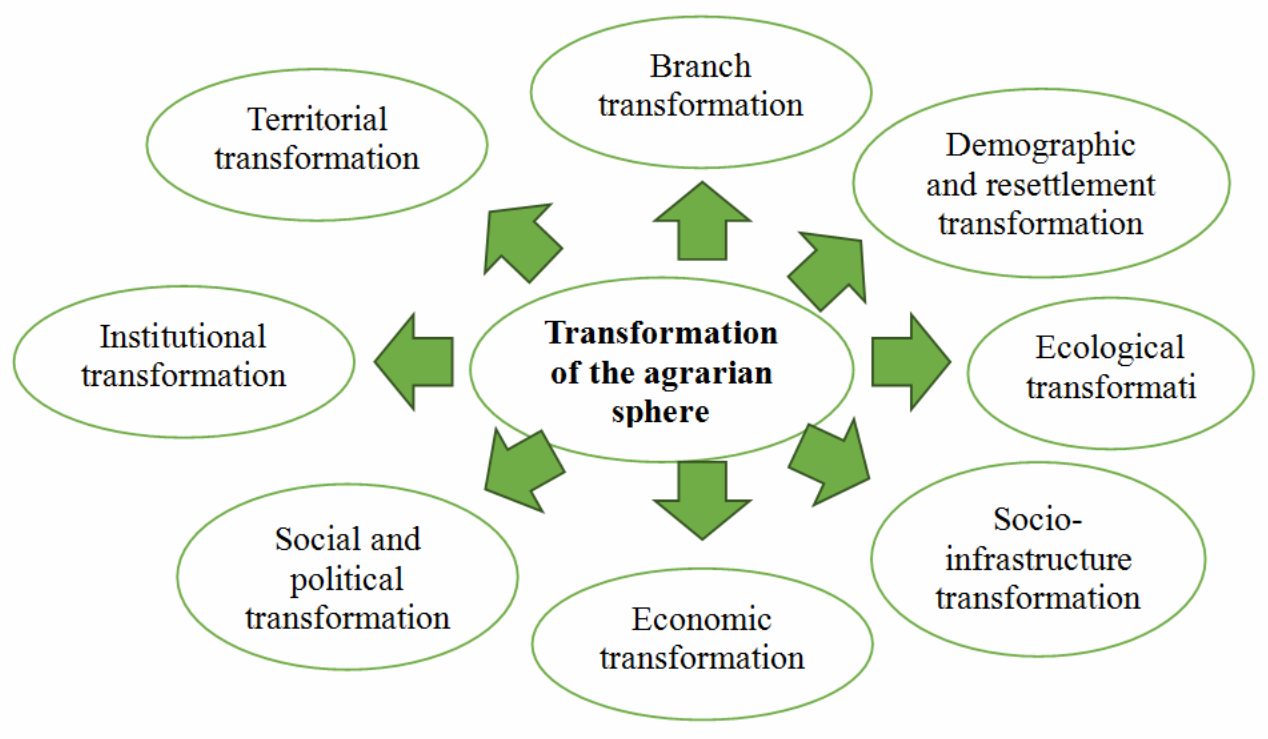

Fig. 2. The structure of the transformation of the agrarian sphere (based on data [11,21])

According to the opinion of I. Leshchyk and H. Pyrih [7], transformation processes in the agrarian sphere are carried out in five directions.

Institutional and economic transformations in Ukraine led to the formation of new forms of management, development of regulatory and legal framework, creation of new markets for agricultural products, change in the organizational structure of the agrarian sector (farms, production cooperatives, private peasant farms, closed and open joint-stock companies, societies with limited liability, etc.). There have been significant changes in the sectoral structure of the agrarian sector, new industries, sub-sectors, types of agricultural activities have been emerged, specialization of agriculture, dynamics of volumes and the structure of agricultural production have changed, and the sown areas have expanded significantly [7, 24].

Land reform, the main task of which was redistribution, transfer into private ownership of most agricultural land, division of the agricultural land and property into shares and their transfer to collective ownership; securing and protecting the right of property of farmers to land $[1,19]$.

Market transformations consist of liberalization and the formation of the agrarian market, replacing the old planning and distribution system for the marketing of agricultural products with a market-based economic mechanism [15].

Financial stabilization - provides for the improvement of the agricultural sector of the economy, reducing taxes, improving the investment and credit climate, reducing price disproportions, unemployment and stabilizing the incomes of the peasants [7].

Social development - is to support the social resources of rural areas, the creation of appropriate social conditions for the normal functioning and development of agricultural enterprises [7, 25].

The modern transformation in the agrarian sphere of Ukraine is a result, in particular the centuries-old institu- tional transformation. The Ukrainian transformation model is characterized by a certain instability in the first stage of the transition; creation of new forms of enterprises, new economic and institutional conditions, modern market infrastructure, as one of the ways out of the transformation stagnation; destruction of the agrarian sphere due to underdevelopment of institutional systems; lack of an optimal model of transition to a new socioeconomic system, different rates of transformation, impossibility of co-existence of old and new forms of management $[3,13,26]$.

The goal of transformation processes in the agrarian sphere of Ukraine, according to T. Ostashko, is: the formation of effective, export-oriented agriculture, which is based on competitive advantages; development of rural areas; ensuring the food security of the state [15].

Most researchers of the agrarian sphere of Ukraine argue that the transformation processes began with independence, in connection with transition from the command-administrative economic system to the free-market system. According to I. Leshchyk and H. Pyrih, transformational processes in the agrarian sphere of the economy began with the development of commodity economy [7]. T. Ostashko, T. Pepa, P. Sabluk believe that crisis phenomena have become aggravated with the transition to a market model of the economy in the agrarian sphere of Ukraine. i.e. transformation processes did not yield the expected results $[15,16,19]$. A. Onyshchenko and V. Yurchyshyn believe that the cause of the decline of the agrarian sphere was the imperfection of agrarian policy and imperfect organization of its implementation [14]. A. Marushchynets notes that the lack of clear goals and goals of transformation is one of the causes of the crisis state of the agrarian sphere [11].

All the transformational processes in the agrarian sphere of Ukraine can be divided into four periods: preSoviet, Soviet, post-Soviet reforms, the modern period (Fig. 3) [7]. 


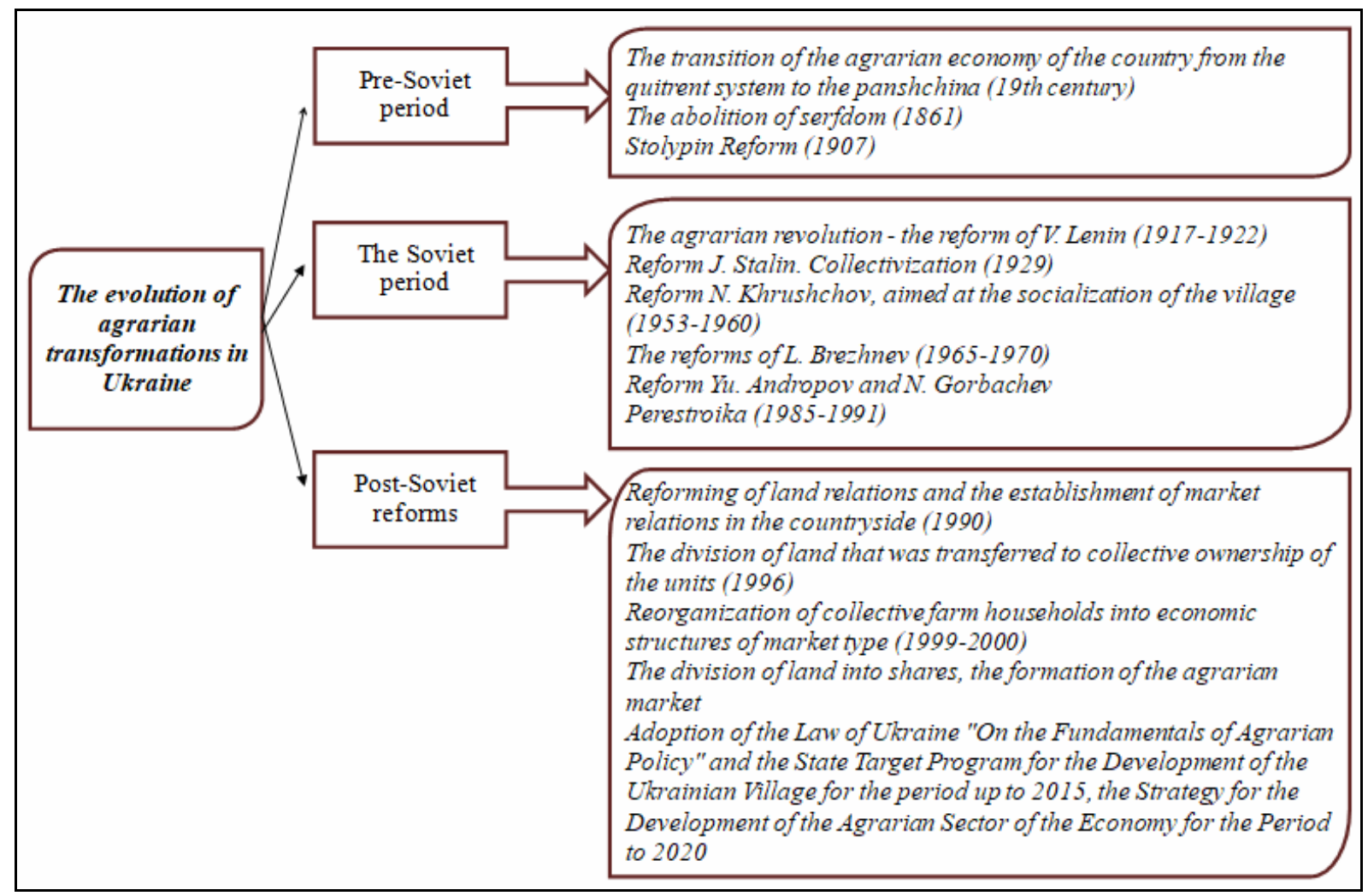

Fig. 3. The structure of the transformation strategy of the agrarian sphere in Ukraine (improved by the authors for [7])

In the post-Soviet period of the early 90 -ies of the twentieth century transformation processes in Ukraine's agrarian sector were characterized by the following changes: land privatization, collective farm reorganization, farming, land relations transformation, obsolete price controls, which led to hyperinflation and disparity of prices. Lack of clear state policy, inconsistency and haste of public authorities, a long period of market transformation quickly led to the decline of the agrarian sphere $[2,11]$.

Transformation processes in the agrarian sphere of Ukraine since the 2000s are characterized by the creation of new production units on the basis of former collective enterprises, their production assets and land plots, division of land into shares, formation of the agrarian market and infrastructure of the agricultural sector, emergence of agroholdings - horizontally and vertically integrated production structures, strengthening of the regulatory and legal framework for the functioning of the agrarian sphere (adoption of the State Targeted Development Program the Ukrainian village for the period until 2015, the Law of Ukraine "On the fundamentals of agrarian policy", Strategy for the development of the agricultural sector of the economy for the period up to 2020) [5, 12].

Transformational processes in the agrarian sphere are the driving force behind the socio-economic development of the regions, especially in the rural areas [28].

According to the given statements R. Smolenyuk developed a strategic framework for transforming the agrarian sphere through the prism of the concept of "balanced development" (Fig. 4) [20]. The achievements of this development take place taking into account the interests of nature and society in the economic, ecological, social aspects.

As a result of the transformation of the agrarian sphere, several effects are achieved: stabilization of the economic, ecological, social spheres of life of the rural population; ensuring improvement in the quality of life of the population, its confidence in a secure future, providing equal opportunities for achieving material, ecological and social well-being, an efficient economy based on rational consumption of material resources, improving the quality of the environment, establishing nature management in the national interests of the country and preserving resources for future generations, increasing life expectancy and stabilizing the population of Ukraine [4, 11, 29].

So, transformation processes in the agrarian sphere of Ukraine are not yet completed and require further thorough research. The socio-geographic approach to the study of transformation processes in the agrarian sphere will make it possible to identify the current state and changes in the territorial organization of the agrarian sector, changes in the sectoral structure, specialization in the distribution of key industries, and reveal the impact of these processes on the socio-economic development of the regions. This is especially true of the specifics of the organization of the agrarian sector at the regional level, since the transformation processes have certain features of the flow in connection with the heterogeneity of the territory of Ukraine and associated with the natural conditions of the territory. 


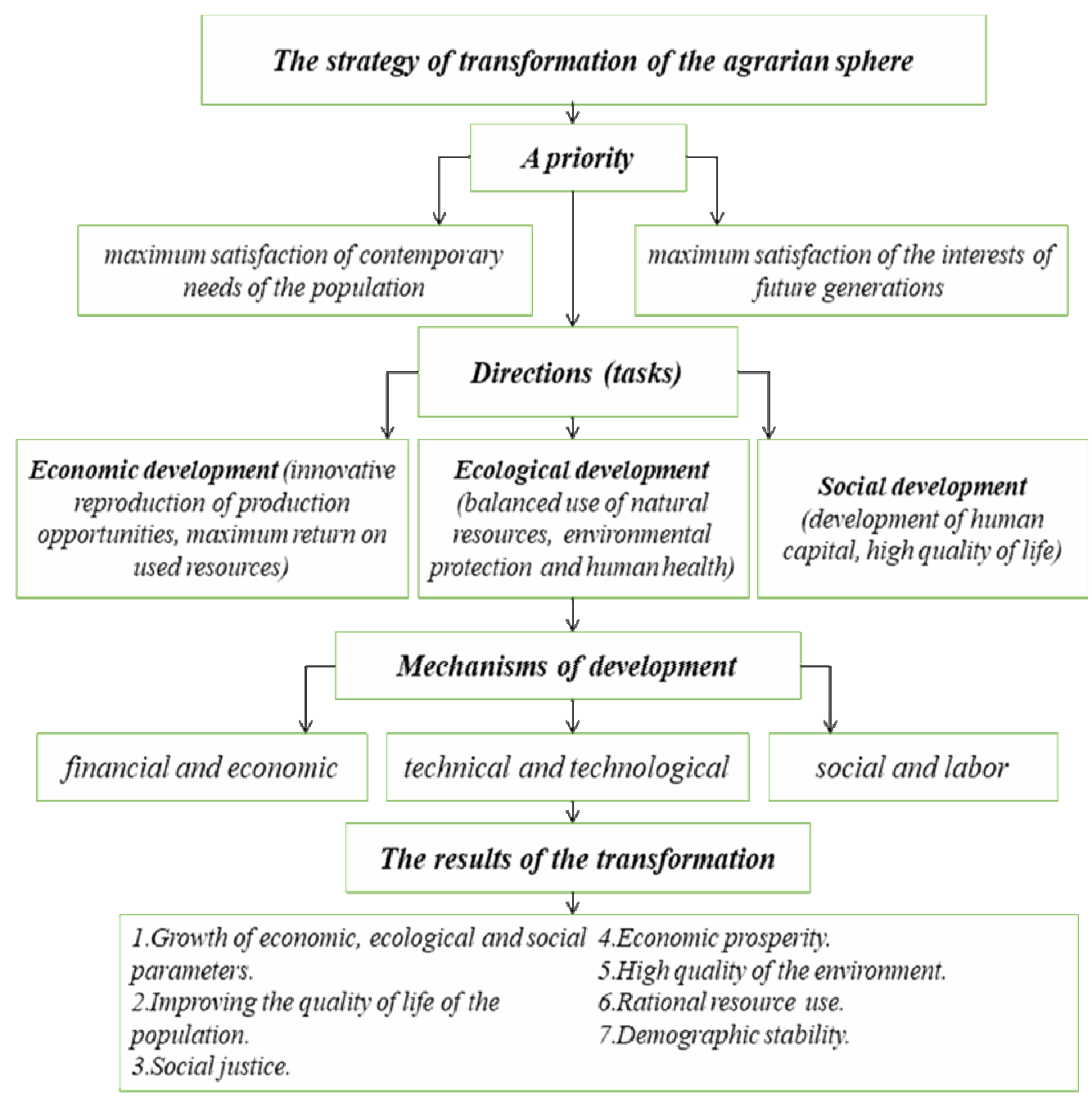

Fig. 4. Strategic structure of transformation of the agrarian sphere (improved by the authors for [20])

Conclusions. The conducted research allows to draw the following conclusions. The absence in the scientific literature of an unambiguous definition of the term "transformation of the agrarian sphere" determines the relevance of this research topic. According to the definitions of human geographers, transformation of the agrarian sphere is a human-geographical process characterized by a change in the sectoral, territorial structure and system of the agrarian sphere on different scales, caused by transformation of the entire economic system or its structural elements. Transformation processes in the agrarian sphere of Ukraine arose due to changes in socio-political, economic, institutional systems, diversity of natural conditions of the territory, demographic situation, social infrastructure, ecological status.

Transformation processes in the agrarian sphere of Ukraine began from the time of its proclamation as an independent state, from the command-administrative economic system to a free market with the aim of form- ing a competitive agricultural product. For the Ukrainian transformation model, the process of transformation is typical in the context of a significant economic downturn in stimulating the privatization processes and imperfection of the agrarian policy, lack of clear goals and mechanisms of action. That is why the expected effects of the transformation on a national scale did not happen.

Therefore, further studies are needed to study the transformational processes of the agrarian sphere from the standpoint of human geography, which will make it possible to consider transformations as a sociogeographical process, to reveal factors and spatial and temporal features of the agrarian sphere, to trace the interrelation of the agrarian sphere with the socioeconomic development of the regions. So, despite the length of transformational processes in the agrarian sphere, the heterogeneity of their flow, it is necessary to analyze territorial features of the manifestation of these processes in the regions of Ukraine.

\section{References:}

1. Haidutskyi, P.I. ed. (2005). Ahrarna reforma v Ukraini [Agrarian reform in Ukraine]. Kyiv: NNC IAE, 424 [in Ukrainian].

2. Balabanov, H.V. (2000). Transformatsiya struktury silskohospodarskoho vyrobnytstva Ukrainy: rehionalnyi aspekt [Transformation of the structure of agricultural production in Ukraine: regional aspect]. UAPP / PAP, 29 [in Ukrainian]. 
3. Heiets, V.M., Kvasniuk, B.Ye., Zveriakov, M.I. (1999). Transformatsiya modeli ekonomiky Ukrainy: ideolohiia, protyrichchia, perspektyvy [Transformation of the model of Ukraine's economy: ideology, contradictions, prospects]. Kyiv, Ukraine: Lohos, 497 [in Ukrainian].

4. Hrazhevska, N.I. (2007). Vidobrazhennya transformatsiinykh protsesiv u systemi katehoriy sotsialnoekonomichnoi dynamiky [Reflection of transformational processes in the system of categories of socio-economic dynamics]. Ekonomichna teoriia - Economic theory, 4, 19-29 [in Ukrainian].

5. Zaiachuk, M.D. (2015). Geoprostorova orhanizatsiya fermerskoho ukladu Ukrainy [Geospatial organization of a farmer device in Ukraine]. Bukret, 520 [in Ukrainian].

6. Kravets, T.M. (2012). Suspilno-geografichni aspekty funktsionalnoi transformatsii ahrarnoi sfery Lvivskoi oblasti [Socio-geographical aspects of the functional transformation of the agrarian sphere of the Lviv region]. Geografiya i turyzm - Geography and Tourism, 23, 209-216 [in Ukrainian].

7. Leshchyk, I.B., Pyrih, H.I. (2013). Orhanizatsiyno-ekonomichni transformatsii v ahrarnomu sektori ekonomiky [Organizational-economic transformations in the agrarian sector of the economy]. Stalyi rozvytok ekonomiky Sustainable development of the economy, 3, 327-331 [in Ukrainian].

8. Lohvynova, M.O. (2018). Naukovi pidkhody do traktuvannya ponyattya «ahrarna sfera» [Scientific approaches to the definition of the concept «agrarian sphere»]. Materialy mizhnarodnoyi naukovo-praktychnoi konferentsii studentiv, aspirantiv ta molodykh naukovtsiv Region-2018: suspilno-geografichni aspekty - Proceedings of the conference Region-2018: socio-geographical aspects. Kharkiv: KhNU, 32-35 [in Ukrainian].

9. Malik, M.Y. (2007). Reformuvannya vlasnosti i restrukturyzatsiya pidpryemstv APK [Property reform and restructuring of agricultural enterprises]. Ekonomika APK - Economy of agroindustrial complex, 11, 9-13 [in Ukrainian].

10. Marushchynets, A.V. (2010). Haluzeva ta terytorialna transformatsiya ahrarnoi sfery Ukrainy [Branch and territorial transformation of the agrarian sphere of Ukraine]. Ekonomika APK - Economy of agroindustrial complex, 2, 652 [in Ukrainian].

11. Marushchynets, A.V. (2016). Transformatsiya ahrarnoi sfery ta sotsialno-ekonomichnyi rozvytok Kyivskoho Prydniprovya [Transformation of the agrarian sphere and socio-economic development of the Kyiv Dnieper]. Kyiv, 196 [in Ukrainian].

12. Mesel-Veselyak, V.Ya. (2010). Ahrarna reforma i orhanizatsiyno-ekonomichni transformatsii v silskomu hospodarstvi [Agrarian reform and organizational-economic transformations in agriculture]. Ekonomika APK Economy of agroindustrial complex, 4, 3-18 [in Ukrainian].

13. Mochernyi, S.V. (2005). Modeli transformatsiynykh protsesiv ekonomiky (teoretyko-metodolohichni aspekty) [Models of transformational processes of economy (theoretical and methodological aspects)]. Ekonomika Ukrainy - Economy of Ukraine, 2, 13-21 [in Ukrainian].

14. Onyshhenko, O.M., Yurchyshyn, V.V. (2006). Silske hospodarstvo, selo i selyanstvo Ukrainy u dzerkali postradyanskoi ahrarnoyi polityky [Agriculture, village and peasantry of Ukraine in the mirror of the post-Soviet agrarian policy]. Ekonomika Ukrainy - Economy of Ukraine, 1, 4-14 [in Ukrainian].

15. Ostashko, T.O. (2004). Rynkova transformaciya ahrarnoho sektora [Market transformation of the agrarian sector]. K.: Feniks, 280 [in Ukrainian].

16. Pepa, T.V. (2006). Regionalna dynamika i transformatsiya ekonomichnoho prostoru Ukrainy [Regional dynamics and transformation of the economic space of Ukraine]. Cherkasy: Brama-Ukraina, 440 [in Ukrainian].

17. Pidhrushnyi, H.P., Marushchynets, A.V. (2016). Transformatsiya spetsializatsii silskoho hospodarstva Kyivskoho Prydniprovya u postsocialistychnyi period: metodyka doslidzhennya i terytorialni osoblyvosti [Transformation of the Specialization of Agriculture of the Kyiv Dnieper in the Post-Socialist Period: Research Methodology and Territorial Peculiarities]. Ukrainskyi geografichnyi zhurnal - Ukrainian geographic journal, 2, 48-56 [in Ukrainian].

18. Pro osnovni zasady derzhavnoi ahrarnoi polityky na period do 2015 roku : Zakon Ukrainy vid 18 zhovt. 2005 r. № 2982-IV. Retrieved from http://zakon3.rada.gov.ua/laws/show/2982-15 [in Ukrainian].

19. Sabluk, P.T., Mesel-Veselyak, V.Ya., Fedorov, M.M. (2009). Ahrarna reforma v Ukraini (zdobutky, problemy i shlyakhy yikh vyrishennya) [Agrarian reform in Ukraine (achievements, problems and ways of their solution)]. Ekonomika APK - Economy of agroindustrial complex, 12, 3-13[in Ukrainian].

20. Smolenyuk, R.P. (2014). Transformatsiya ahrarnoho sektora ekonomiky na zasadakh staloho rozvytku [Transformation of the agricultural sector of the economy on the basis of sustainable development]. Innovatsiyna ekonomika - Innovative economy, 6, 14-20 [in Ukrainian].

21. Sosnytska, Ya.S. (2015). Suchasni transformatsiyni protsesy silskohospodarskoho vyrobnytstva (na prykladi Volynskoi oblasti) [Modern transformational processes of agricultural production (on the example of the Volyn region)]. Lutsk: Skhidnoevropeyskyi natsionalnyi universytet imeni Lesi Ukrainky, 226 [in Ukrainian].

22. Sosnytska, Ya.S. (2015). Transformatsiyni protsesy u silskomu hospodarstvi, yak obyekt doslidzhennya suspilnogeografichnymy naukamy [Transformational processes in agriculture as a subject of research by sociogeographical sciences]. Naukovyi oglyad - Scientific inspection, 13, 54-60 [in Ukrainian].

23. Sukhyi, P.O. (2008). Ahroprodovolchyi kompleks Zakhidnoukrainskoho regionu [Agro-food complex of Western Ukraine Region]. Chernivtsi: Ruta, 400 [in Ukrainian].

24. Trehobchuk, V.M., Pradun, V.P. (2004) Ahrarna sfera: model staloho rozvytku [Agrarian sphere: the model of sustainable development]. Visnyk NAN Ukrainy - Bulletin of NAS of Ukraine, 9, 5-16 [in Ukrainian]. 
25. Turylo, A.M., Kornukh, O.V. (2014). Ekonomichna transformatsiya yak klyuchove ponyattya suchasnoho hromadskoho rozvytku [Economic transformation as a key concept of sustainable development]. Naukovyi visnyk Khersonskoho derzhavnoho universytetu. Seriya: Ekonomichni nauky. - Scientific Newsletter of Kherson State University. Economic sciences, 6(3), 189-191 [in Ukrainian].

26. Chernyuk, L.H. (2011). Transformatsiyni protsesy v ekonomitsi Ukrainy ta yii regionakh: problemy ta perspektyvy [Transformation processes in the economy of Ukraine and its regions: problems and prospects]. Zbirnyk naukovykh prats VNAU. - Seriya: Ekonomichni nauky. - Collection of scientific papers VNAN. Economic sciences, 1(48), 252-256 [in Ukrainian].

27. Bachev, H., Tsuji, M. (2001). Structures for Organization of Transactions in Bulgarian Agriculture. Journal of the Faculty of Agriculture of Kyushu University, 46(1), 123-151 [in English].

28. Bański, J., Bednarek, M. (2008). Agriculture of Central Europe in the period of economic transformation. Contemporary changes of agriculture in East-Central Europe, Rural Studies, 15, 9-22 [in English].

29. Kovacs, K., Osamu, I. (2002). Agricultural Restructuring in Hungary and Its Social Impacts. Transformation and Diversification of Rural Societies in Eastern Europe and Russia. Slavic Research Center Hokkaido University, Sapporo, 247-272 [in English].

30. Karácsonyi, D. (2010). The Ukrainian agrarian sector and the global economic crisis. East European Studies, IWE HAS, 91-138 [in English].

Надійшла до редколегї 05.05.2018 p. 